\title{
Improvement of the Model for Calculating the Operating Profit of Industrial Enterprises Taking into Account the Problem of Optimal Distribution of Productive Resources
}

\author{
Ruslan Skrynkovskyy ${ }^{1}$, Lyubomyr Sopilnyk ${ }^{1}$, Fedir Horbonos ${ }^{1}$, Sviatoslav Kniaz ${ }^{2}$, \\ Nataliia Pavlenchyk ${ }^{3}$, Volodymyr Yuzevych ${ }^{4}$
}

${ }^{1}$ Lviv University of Business and Law

99 Kulparkivska Street, Lviv, 79021, Ukraine

${ }^{2}$ Lviv Polytechnic National University

12 Stepana Bandery Street, Lviv, 79013, Ukraine

${ }^{3}$ Lviv State University of Physical Culture

11 Kostiushko Street, Lviv, 79000, Ukraine

${ }^{4}$ Karpenko Physico-mechanical Institute of the NAS of Ukraine

5 Naukova Street, Lviv, 79601, Ukraine

DOI: $10.22178 /$ pos.44-2

JEL Classification:

C01, D24, M11, M21, M54

Received 20.02.2019

Accepted 27.03.2019

Published online 31.03.2019

Corresponding Author:

Sviatoslav Kniaz

svkniaz@ukr.net

(C) 2019 The Authors. This article

is licensed under a Creative

Commons Attribution 4.0 License

(c) (1)

\begin{abstract}
On the ground of the conducted research, based on the stated goals and objectives, the model of calculating the operating profit of industrial enterprises, which is based on economic and mathematical dependencies, and takes into account the problem of optimal distribution of production resources in the system of operational management has been improved. Great attention has been paid to the analysis of the cost factors in the system of analysis of the ratio of "costs - volume - profit", the definition of the optimal distribution of productive resources from the set of possible (admissible) ones in the organization of labor and production, the difference between accounting and economic approaches to calculating profit, the difference in approaches to the classification of overhead costs in terms of activity-based costing.
\end{abstract}

Keywords: industrial enterprises; operating profit; production resources; optimal allocation of resources; operational management; management decisions.

\section{INTRODUCTION}

The practice of conducting business shows that the main (and most effective) way to increase the level of financial stability and competitiveness of industrial enterprises is to increase their profitability by increasing production [1, 2, 3]. Among the types of company's profit according to the sources of its formation (operating profit, profit from the property sale, profit from non-operating operations [4]) the main role belongs to operating profit (or profit from the main activities of the enterprise, i.e., from production and sales).
In this context, experts estimate that today the share of operating profit of an industrial enterprise in Ukraine accounts for $90-95 \%$ of the total value of its balance profit. Here (in calculating the operating profit of an enterprise), based on the subject of the research of operations [5], regarding the quantitative substantiation of decisionmaking (economic, organizational, technological, technical, etc. [6]) on the management of organizations, a great importance is given to the task of optimal allocation of productive resources of the enterprise in the system of organization of work and production (or in the system of operational management). 
Analysis of recent studies and publications shows that the theory of $[4,6,7]$ and practice clearly state the existence of the relationship between cost, revenue and profit. In addition, existing solutions to problems in the formation of operating profit and the order of its calculation and distribution, including the mechanisms for managing it, are presented in the works $[1,2,3]$. At the same time, it should be noted that the object of heated discussions is the peculiarities of the formation and use of the economic and mathematical model for calculating the operating profit of industrial enterprises and determining the optimal allocation of production resources in the system of operational management. All this conditioned the relevance of the study, determined its theme and directions.

Thus, the purpose of the work is to formulate the theoretical positions and develop practical recommendations for improving the model for calculating the operating profit of industrial enterprises, taking into account the problem of optimal allocation of production resources in the system of operational management.

To achieve this goal, the following scientific tasks are identified:

1. To clarify the essence of the category "operating profit of the enterprise".

2. To offer a toolkit (or economic and mathematical apparatus) for determining the optimal distribution of productive resources in the system of economic and mathematical dependencies, which collectively form a model for calculating the operating profit of industrial enterprises.

\section{RESEARCH RESULTS}

On the basis of the results of the research $[1,4]$, it can be stated that operating profit (profit from sales of goods) of the enterprise is the income, obtained from sales of products (works, services) of the enterprise, reduced by the amount of the accrued (paid) value added tax, excise duty, and also by the amount of expenses included in the cost of sold products (works, services) [4]. At the same time, the financial-economic dictionary [4] states that:

1) the volume of sales of products (works, services) is the cash income from the sale of products (works, services) for a certain period of time (month, quarter, year, etc.);
2) the production cost of products (works, services) includes:

- direct material expenses;

- direct labor cost expenses;

- other direct expenses;

- total expenditures:

a) fixed expenses - the cost of resources (material and labor) for the production (or production (technological) process of manufacturing) of products (works, services) of the enterprise, which do not depend on the volume of production, but conditioned only by the structure and organization of production management); b) variable (direct) expenses - the cost of material and labor resources (employees' wages) for the manufacturing of products (works, services) of enterprises, varying in proportion to the change in production volume.

Along with that, the conducted research $[2,7,8]$ allows us to conclude the following: the formation of operating profit of an industrial enterprise is carried out under the influence of a number of factors (external, internal) which need to be foreseen in financial planning. Here, based on the opinion of experts, it is advisable to take into account the following two aspects: 1) analysis of the factors of expenditure $[9,10,11]$; 2) determination of the optimal (the best) distribution of productive resources out of the set of possible (admissible) in the system of operational management $[5,12,13,14]$.

Thus, taking into account the information in the paper [1], the operating profit of an industrial enterprise within the base period (month, quarter, year) will be denoted as $P_{0}$, the volume of sales of industrial products (goods, works, services) is $O_{0}$, and the variable (direct) costs are $V_{0}^{z}$.

At the same time, we assume that the fixed costs $\left(V^{p}\right)$ of the industrial enterprise remain unchanged throughout the forecast period (month, quarter, year), that is, we write down the corresponding formula $(1)[1,4]$ :

$$
P_{0}=O_{0}-\left(V_{0}^{z}+V^{P}\right)
$$

In view of this, similarly to formula (1), we write formula (2) [1] - for calculating the operating profit of an industrial enterprise in the first defined forecast period (month, quarter, year): 


$$
P_{1}=O_{1}-\left(V_{1}^{z}+V^{P}\right)
$$

Let the sales volume of an industrial enterprise (within a certain (specific) period of time) increases in $x$ times - formula (3):

$$
O_{1}=x \cdot O_{0}
$$

It is also worth noting that since the variable costs of an industrial enterprise (proportional (linear), progressive, and degenerate [4]) increase in proportion to the increase in sales volumes, then, respectively, formula (4) [1]:

$$
V_{1}^{z}=x \cdot V_{0}^{z}
$$

So, in support of the author's suggestion [1] that, if we substitute formulas (3) and (4) into formula (2), we obtain the value of the operating profit of an industrial enterprise in the first forecast year according to formula (5):

$$
P_{1}=x \cdot\left(O_{0}-V_{0}^{z}\right)-V^{P} .
$$

Taking into account the effect of the production (or operational) lever $[1,13,14]$, we will see that any change in the volume of revenue from sales of industrial products generates an even more significant change in the amount of its profit. At the same time, we assume that the growth rate of operating profit is some (specific) value of $y_{1}$, which can be given by formulas (6) and (7) [1]:

$$
\begin{aligned}
& y_{1}=\frac{P_{1}-P_{0}}{P_{0}}, \\
& y_{1}=\frac{(x-1) \cdot\left(O_{0}-V_{0}^{z}\right)}{O_{0}-V_{0}^{z}-V^{P}} .
\end{aligned}
$$

From this it is obvious that according to formula (3) and taking into account the corresponding transformations [1]:

1) the sales volume in the $n$-forecast period (month, quarter, year) will be (8):

$$
\begin{aligned}
& O_{2}=x \cdot O_{1}=x^{2} \cdot O_{0} \\
& \ldots \\
& O_{n}=x \cdot O_{n-1}=x^{n} \cdot O_{0}
\end{aligned}
$$

2) the variable (direct) costs of an industrial enterprise in the $\mathrm{n}$-forecast period (month, quarter, year) are determined by the formula (9) (similar to the volume of sales (8)):

$$
\begin{aligned}
& V_{2}^{z}=x \cdot V_{1}^{z}=x^{2} \cdot V_{0}^{z} \\
& \cdots \\
& V_{n}^{z}=x \cdot V_{n-1}^{z}=x^{n} \cdot V_{0}^{z}
\end{aligned} .
$$

Consequently, the operating profit of an industrial enterprise in the $n$-forecast period (month, quarter, year) is recommended to be calculated by the formula (10) [1]:

$$
P_{n}=x^{n} \cdot\left(O_{0}-V_{0}^{z}\right)-V^{P} \text {. }
$$

Here (in the costs of production and sales of industrial enterprises), based on the results of the analysis of literary sources $[9,11,12,14]$, it is expedient to take into account the analysis of structural and executive factors of costs (Table 1) in the system of analysis of the ratio of "costs - volume - profit" and predict: 1) the difference between the accounting and economic approach to calculating profits, which is illustrated in the works $[9,12]$; 2) the difference in approaches to the classification of overhead costs in terms of activity-based costing (Table 2).

Table 1 - Cost factor analysis [9]

\begin{tabular}{|l|l|}
\hline Structural cost factors & Execution cost factors \\
\hline - Scope of activity & - Quality and \\
- Sphere (vertical & reliability \\
integration) & - Use of power \\
- Experience of activity & - Potential of labor \\
- Technology & force** \\
- Complexity of activity & - Designing production \\
& - Relations with \\
& suppliers and \\
& customers \\
\hline
\end{tabular}

Notes: *The main types of quality at an enterprise are: constructive quality, production quality, quality of marketing and services [15].

** Here the educational and professional potential of the workers of the main and auxiliary production plays an important role $[16,17]$. 
Table 2 - Difference in the approaches to the classification of overhead costs in terms of activitybased costing [9]

\begin{tabular}{|l|l|}
\hline $\begin{array}{l}\text { Traditional } \\
\text { approach }\end{array}$ & Activity-based costing \\
\hline Variable costs & $\begin{array}{l}\text { Short-term variable costs } \\
\text { (volume related) }\end{array}$ \\
\hline Constant costs & $\begin{array}{l}\text { Long-term variable costs not } \\
\text { related to volume) }\end{array}$ \\
\cline { 2 - 2 } & Long-term constant costs \\
\hline
\end{tabular}

At the same time, according to the results of the research $[5,14,15,17]$ it was established that the production process, the quality and optimal distribution of production resources, logistics and effective motivation of employees are the main factors that lead to non-defectiveness and rhythm of production, that is, affect the level of production quality of an industrial enterprise. Here an important task, based on the organizational and technological structure of the enterprise, job descriptions, which establish the rights and responsibilities of specific workers, is the creation and maintenance of the operation of the accounting system of the enterprise for such centres of responsibility as cost centre, income centre, profit centre and investments centre [9].

At the same time, it was ascertained $[1,5,13]$ : the growth rate of operating profit of an industrial enterprise in the $n$-forecast period (month, quarter, year) is calculated by the formula (11):

$$
y_{n}=\frac{P_{n}-P_{n-1}}{P_{n-1}} \text {, }
$$

where $P_{n-1}$ respectively (similarly) to formula (10), is calculated by the formula (12):

$$
P_{n-1}=x^{n-1} \cdot\left(O_{0}-V_{0}^{z}\right)-V^{P}
$$

On the basis of changing (transformation) of formula (1) we obtain the formula (13):

$$
O_{0}-V_{0}^{z}=P_{0}+V^{P}
$$

Substituting formula (12) in (11) and, having made the corresponding (concrete) transforma- tions and reductions, taking into account (13), we obtain the expression (14) [1]:

$$
P_{n}=\left(y_{n}+1\right) \cdot\left(x^{n-1}\left(P_{0}+V^{P}\right)-V^{P}\right) .
$$

Thus, the ratio (14) characterizes the economicmathematical model for calculating the amount of operating profit of an industrial enterprise, based on the rate of its growth in the $n$-period (month, quarter, year) and potential growth rates of sales in the previous $(n-1)$ period (month, quarter, year) [1, 12, 13, 14, 18, 19, 20].

As for the definition of the optimal distribution of productive resources (labor, material, financial, energy $[12,21])$ of an industrial enterprise in the system of operational management, the corresponding optimization problem, taking into account the theory $[5,22]$ and business practice, will be presented in more detail below.

Thus, the meaningful statement of the problem is the following [5]: an industrial enterprise can produce (or produces) $n$ different types of industrial products (works, services), using for this purpose $m$ types of productive resources (labor, material, financial, energy [21]); the quantity of the $i$-resource that an industrial enterprise can use for production (industrial consumption) in the planned period, should not exceed $b_{j}$ units $(j=\overline{1, m})$; known data: $a_{i j}$ is the cost of $j$-resource ( $j=\overline{1, m}$ ) for the production of the output of the $i$-product of the industrial enterprise; $P_{i}$ - the profit expected by the enterprise from the sale of the $i$-product $(i=\overline{1, n})$; it is necessary to find such resource allowable volumes of production of each type of products (works, services), at which the total expected operating profit of the industrial enterprise from the sale of products will be the largest; let $x_{i}$ be the volume of production of the $i$-industrial product $(i=\overline{1, n})$.

In this context (in accordance with the meaningful statement of the problem of optimal distribution of industrial resources of an industrial enterprise), we will construct an economic-mathematical model corresponding to the formulated problem - formulas (15)-(17) [5], that is to find:

$$
x_{i} \geq 0
$$


which is in the domain $G$, defined by the conditions (16):

$$
\sum_{i=1}^{n} a_{i j} x_{i} \leq b_{j}, j=\overline{1, m}
$$

and maximize the function (17):

$$
Z=\sum_{i=1}^{n} P_{i} x_{i}
$$

Here one should also agree with the authors' opinion [5] that the economic-mathematical model (15)-(17) is a task of linear programming. At the same time, it is advisable to note $[5,12$, 14]: the presented problem is solved, as a rule, not to all production factors, but only to those, which are scarce, and the graphic volume of possible production (production consumption) of which is limited within the planned period and affects the final result of the industrial activity of the industrial enterprise (obtaining the integral effect (result) [12]). As for the other (additional) production factors that can be used in an arbitrary quantity, based on the information in [13, 14], they can be ignored in solving the problem (15)-(17). Therefore, after finding the optimal volumes of industrial production, $x_{1}{ }^{*}, x_{2}{ }^{*}, x_{3}{ }^{*}, \ldots$, $x_{n}{ }^{*}$ the required utilization of resources (labor, material, financial, energy [12, 21]), and their optimal distribution are calculated according to the norms of the costs of these resources per unit of each type of product. The given method is the basis of matrix planning, when the needs for productive resources are determined by the product of the specific resource consumption matrix for the volume production vector [5].

In this context it should be noted that when constructing the model (15)-(17) it is taken into account that the market is unsaturated, and therefore, all products made by the industrial enterprise will be realized [5]. However, if this condition does not exist, then the economicmathematical model (15)-(17) needs to be supplemented with additional (specific) constraints on the implementation of the corresponding products, based on additional research that de- termines the prospects for further development in this direction.

The presented research is the continuation of the cycle of works, in particular $[1,5,12,13,21,23$, 24], which should be considered when improving the system of diagnostics and monitoring of financial and economic activity of industrial enterprises.

\section{CONCLUSION}

1. Based on the results of the research, the essence of the category "operating profit of the enterprise" was specified. According to the authors of this work, the operating profit (profit from sales of goods) of the enterprise is the income, obtained from sales of products (works, services) of the enterprise, reduced by the amount of the accrued (paid) value added tax, excise duty, as well as by the amount of expenses, included in the cost of sold products (works, services). At the same time, it was found out that the formation of operating profit is influenced by a wide range of factors that characterize all aspects of financial and economic activity of enterprises. Here it is expedient: 1) to take into account such aspects as analysis of cost factors in the system of analysis of the ratio "cost - volume - profit" and the definition of the optimal (best) distribution of production resources from the set of possible (admissible) ones in the system of operational management; 2) predict the difference between the accounting and economic approaches to calculating profit and the difference in approaches to the classification of overhead costs in terms of activity-based costing.

2. The scientific novelty of the obtained results lies in the improvement of the model for calculating the operating profit of industrial enterprises, which, in contrast to the existing:

- takes into account the problem of the optimal (best) distribution of productive resources (labor, material, financial, energy) from the set of possible in the system of operational management;

- is aimed at the formation and support of managerial decisions in the system of organization of work and production (or in the system of operational management). 


\section{REFERENCES}

1. Ishchuk, S. (2009). Model rozrakhunku operatsiinoho prybutku promyslovykh pidpryiemstv [Model for calculating the operating profit of industrial enterprises]. Economy and Forecasting, 3, 134143 (in Ukrainian).

2. Cherleniak, I., Poida-Nosyk, N., \& Havrylko, P. (2011). Osoblyvosti formuvannia operatsiinoho prybutku ta mekhanizmy upravlinnia nym [Features of the formation of operating profit and its management mechanisms]. Scientific bulletin academy of municipal administration, 10, 80-88 (in Ukrainian).

3. Whiting, E. (1986). Operating profit. A Guide to Business Performance Measurements, 81-98. doi: 10.1007/978-1-349-07472-3_8

4. Zahorodnii, A., \& Vozniuk, H. (2005). Finansovo-ekonomichnyi slovnyk [Financial and Economic Dictionary]. Lviv: Vydavnytstvo Natsionalnoho universytetu "Lvivska politekhnika" (in Ukrainian).

5. Karahodova, O., Kihel, V., \& Rozhok, V. (2007). Doslidzhennia operatsii [Operations Research]. Kyiv: Tsentr uchbovoi literatury (in Ukrainian).

6. Tsiutsiura, S., Kryvoruchko, O., \& Tsiutsiura, M. (2012). Teoretychni osnovy ta sutnist upravlinskykh rishen. Modeli pryiniattia upravlinskykh rishen [Theoretical foundations and essence of managerial decisions. Models of making managerial decisions].Management of Development of Complex Systems, 9, 50-58 (in Ukrainian).

7. Panchenko, I. (2012). Klasyfikatsiia prybutku dlia tsilei bukhhalterskoho obliku, analizu ta kontroliu: krytychnyi analiz isnuiuchykh pidkhodiv [Profit classification for accounting, analysis and control purposes: a critical analysis of existing approaches]. Problems of Theory and Methodology of Accounting, Control and Analysis, 1(22), 224-236 (in Ukrainian).

8. Ustinova, I., Budishcheva, I., \& Domaradzka, H. (2000). Operatsiinyi analiz yak skladova mekhanizmu upravlinnia prybutkom pidpryiemstva [Operational analysis as a component of the management mechanism of enterprise profits]. Problemy ekonomiky ta upravlinnia, 391, 183-188 (in Ukrainian).

9. Holov, S. (2007). Bukhhalterskyi oblikv Ukraini: analiz stanu ta perspektyvy rozvytku [Accounting in Ukraine: An Analysis of the Status and Prospects of Development]. Kyiv: Tsentr uchbovoi literatury (in Ukrainian).

10. Zahorodnii, A., Bilyk, M., \& Kindratska, H. (2010). Operatsiinyi analiz u systemi upravlinnia prybutkom subiektiv hospodariuvannia [Operational analysis in the management system of profits of business entities]. Proceedings of Cherkasy state technological university. Series: Economic sciences, 25(1), 22-25 (in Ukrainian).

11. Porter, M. (1980). Competitive Strategy: Techniques for Analyzing Industries and Competitors. New York: Free Press.

12. Skrynkovskyy, R., Pavlenchyk, N., Horbonos, F., \& Protsiuk, T. (2018). Improvement of the express diagnostics of the production activity of the enterprise taking into account the method of determining the optimal production programs in the operational management system. Technology Audit and Production Reserves, 6(44). doi: 10.15587/2312-8372.2018.147968

13. Ishchuk, S. (2006). Vyrobnychyi potentsial promyslovykh pidpryiemstv: problemy formuvannia $i$ rozvytku [Industrial potential of industrial enterprises: problems of formation and development]. Lviv: IRD NAN Ukrainy (in Ukrainian)

14. Popovych, P. (2004). Economic analysis of subjects of management [Economic analysis of business entities]. Ternopil: Ekonomichna dumka (in Ukrainian)

15. Skrynkovskyy, R. (2015). Kompleksna diahnostyka rozvytku pidpryiemstva: kontseptsiia, parametry, metody [Complex diagnostics of enterprise development: concept, parameters, methods]. Ekonomika. Upravlinnia. Innovatsii, 1. 
16. Doronina, M., Lytovchenko, I. (2010). Systematyzatsiia chynnykiv osvitno-fakhovoho potentsialu vyrobnychoi orhanizatsii [The systematization of factors of educationally professional potential of production organization]. Zbirnyk naukovykh prats ChDTU. Seriya: Ekonomichni nauky, 25, 8185 (in Ukrainian).

17. Skrynkovskyy, R., Protsiuk, T., Ogirko, O., \& Pavlenchyk, N. (2018). Comprehensive Assessing the Enterprise Development Considering the Educational and Professional Potential of Employees in Management System. Journal of Applied Management and Investments, 7(4). 246-255.

18. Ishchuk, S. (2005). Finansovyi mekhanizm upravlinnia vyrobnychym potentsialom promyslovykh pidpryiemstv na innovatsiinykh zasadakh [Financial mechanism for managing the industrial potential of industrial enterprises on an innovative basis].Economy and region, 2(5), 134-137 (in Ukrainian)

19. Brihkhem, Ye. (1997). Osnovy finansovoho menedzhmentu [Fundamentals of Financial Management]. Kyiv: Molod (in Ukrainian)

20. Van Horne, J. C. (1989). Fundamentals of financial management. Englewood Cliffs: Prentice Hall.

21. Skrynkovskyy, R. (2015). Diagnostics of Utilization of the Human, Material, Financial, and Energy Resources of the Enterprise as a Tool for Management of the Elements of Its Production and Commercial Operations. The Problems of Economy, 1, 249-254 (in Ukrainian).

22. Hetman, O., \& Shapoval, V. (2007). Ekonomichna diahnostyka [Economic diagnostics]. Kyiv: Tsentr navchalnoi literatury (in Ukrainian)

23. Horbonos, F., Skrynkovskyy, R., Protsiuk, T., \& Ogirko, I. (2017). Improvement of the Toolkit for Diagnosing the Enterprise's Production Program. Path of Science, 3(12), 4015-4022. doi: 10.22178/pos.29-8 (in Ukrainian).

24. Skrynkovskyy, R., Horbonos, F., \& Pavlenchyk, A. (2018, November 23). Zadacha optymizatsii vyrobnychoi prohramy pidpryiemstva [The task of optimizing the enterprise's production program]. Anti-Crisis Management: State, Region, Enterprise (pp. 119-120). Le Mans: Baltija Publishing (in Ukrainian). 